Снежана Божанић

Универзитет у Новом Саду

Филозофски факултет

Одсек за историју

sbozanic@yubc.net
Оригинални научни рад

примљено: 15. јун 2011

прихваћено: 1. октобар 2011

\title{
ОРОНИМИ У СРПСКИМ СРЕДЊОВЕКОВНИМ ПОВЕЉАМА: ЊИХОВ ПОМЕН У ФУНКЦИЈИ ПОГРАНИЧНОГ ЕНТИТЕТА ПРОСТОРА*
}

Сажетак: Рељеф је један од најважнијих и најутицајнијих елемената природне средине. Сви облици Земљине површине, односно равнине и неравнине на њој, предодређују врсту и облике међашења на неком простору. Планине, брда, брежуљци, врхови брда и планина, главе, гребени, литице, стене, хридине, стрмине, ртови, долине и пољане јављају се у функцији међника. Ороними су јасни, прецизни, лако уочљиви, непокретни, трајни међници који егзистирају под истим или сличним именом од средњег века до данашњих дана.

Кључне речи: средњи век, Србија, међник, ороним, рељеф, планина, брдо, брежуљак, врх, гребен, стена, рт, стрмина, глава, дел, дол, пољана.

Рељеф је један од најважнијих и најутицајнијих елемената природне средине. ${ }^{1}$ Сви елементи природне средине међусобно су повезани и условљени. Природа неког простора представља оквир где људи живе и раде. Физичкогеографске карактеристике природне средине утичу, између осталог, на начин живота становништва. Разликује се живот људи у брдско-планинским подручјима у односу на равничарске и питоме крајеве.

Од рељефа као најважнијег природног фактора у великој мери зависе клима, распоред биљног света, састав земљишта као и правац и брзина водених токова. Облици Земљине површине, односно равнине и неравнине на њој, предодређују врсту и облике међашења на неком простору. Дакле, разграничење неког простора зависи пре свега од конфигурације земљишта. ${ }^{2}$ Планине, брда,

\footnotetext{
* Рад је настао као фазни резултат републичког пројекта број 177002 под називом Војвођански простор у контексту европске историје.

${ }^{1}$ О елементима природне средине погледати: Т. Ракићевић, Опита физичка географија, Београд 1985.

${ }^{2}$ Лексикон српског средњег века, приредили Сима Ћирковић и Раде Михаљчић, Београд 1999, 391-392 (Р. Михаљчић).
} 
брежуљци, врхови брда и планина, главе, гребени, литице, стене, хридине, стрмине, ртови, долине и пољане јављају се у функцији међника прилога у српским средњовековним повељама. То су јасни, прецизни, лако уочљиви, непокретни, трајни међници који егзистирају под истим или сличним именом до данашњих дана.

Миодраг Ал. Пурковић је у својој студији „Одређивање међа” још давно истакао опште прихваћену чињеницу да се од најстаријих времена тежило „да се створи природна међа". Међу најчешће међашке објекте Мирко Барјактаровић убраја, између осталог, брдо, врх, рт, планине, крш, стене и друго. ${ }^{4}$ Када се анализирају диспозиције средњовековних повеља, у првом реду оне из прве половине XIV века које дају највише података за ову тему, лако се може констатовати да се најчешће као међници јављају ороними и хидроними. ${ }^{5}$ Детаљно проучавајући међе у Светостефанској хрисовуљи, Синиша Мишић је констатовао да су дел, брдо и дол најчешћи ороними који се јављају у функцији међника. ${ }^{6}$ Ороними ce јављају као најчешћи међници и у Грачаничкој повељи ${ }^{7}$, Дечанским хрисовуљама $^{8}$, Светоарханђеловској ${ }^{9}$ и Раваничкој повељи. ${ }^{10}$ Намера аутора овог текста није била да се попишу сви ороними који се јављају као међници у српским средњовековним повељама нити су анализиране све повеље. Приказани су само најкарактеристичнији примери који указују на њихов значај и улогу за историју међашења у средњем веку.

„Планине” у средњем веку су сувати, високи планински пашњаци, који су се налазили на надморској висини већој од $1000 \mathrm{~m} .{ }^{11}$ Оне су у средњем веку, пре свега, биле предмет давања и омеђивања. Међутим, оне се често јављају и у функцији међника. Бележе се као погранични ентитет, у највећем броју случајева,

\footnotetext{
${ }^{3}$ Миодраг Пурковић, Одређивање међа, Етнологија 1-2 (1940), 65; Константин Јиречек међу најчешће међнике убраја „камење, стење и литице, долине и јендеке, поједина дрвета, групе дрвећа и шуме, изворе, потоке, локве, рибњаке или баруштине, путеве и раскршћа, мостови и газови, стара гробишта и гробне умке, цркве, градишта и таргове запустелих насеља", Константин Јиречек, Историја Срба II, Београд 1981, 161.

${ }^{4}$ Мирко Барјактаревић, О земљишним међама у Срба, Београд 1952, 38-40.

${ }^{5}$ Синиша Мишић, Унутрашње воде и њихово коришћење у средњовековној Србији, додатак ИГ 1-2/ 1990-1992, (1992), 1-79; Снежана Божанић, Хидрографски међници у српским средњовековним повељама: друштвена, религијска и митолошка функиија, Зборник радова Извори о историји и култури Војводине, Нови Сад 2009, 43-64.

${ }^{6}$ О врстама међника у Светостефанској хрисовуљи погледати опширније у исцрпној расправи код: Синиша Мишић, Међе у Светостефанској хрисовуљи, Манастир Бањска и доба краља Милутина: Зборник са научног скупа одржаног од 22. до 24. октобра 2005. године у Косовској Митровици, Ниш Косовска Митровица - Манастир Бањска 2007, 43-53.

${ }^{7}$ Радомир Ивановић, Земљишни поседи Грачаничког властелинства, ИЧ ХІ (1961), 253-264.

${ }^{8}$ Радомир Ивановић, Дечанско властелинство, историјско-географска обрада, ИЧ IV 1952-1953 (1954), 173-226.

${ }^{9}$ Радомир Ивановић, Властелинство манастира св. Арханђела код Призрена, историјско-географска истраживања, ИЧ VII (1957), 345-359; Радомир Ивановић, Властелинство манастира св. Арханђела код Призрена II, историјско-географска истраживања, ИЧ VIII 1958 (1959), 209-253

${ }_{10}$ Гавро Шкриванић, Раваничко властелинство, историјско-географска истраживања, ИЧ XVI-XVII 1966-1967 (1970), 235-253.

${ }^{11}$ Опширније погледати рад: Милош Благојевић, Планине и пашњаци у средњовековној Србији (XIII-XIV век), ИГ 2-3 (1966), 3-95.
} 
села, групе села, засеока али и као међници других планина. При описивању међа неког села или засеока присуство планина као граничника сведочи, пре свега, о конфигурацији тла. Међе најчешће иду „у планину”, „уз врх планине”, „у врх планине” и ,поврх планине”. Планине и планински врхови заузимају посебно место у словенској и српској митологији. ${ }^{12}$

Према Светостефанској хрисовуљи међа села Сочанице ишла је „у Галич, у Лисац, у Брезову главу, у Јоакимово катуниште, над Козице у планину”. ${ }^{13}$ Планина Лисац бележи у међама села Копорићи, Граничани, Дабрхаве и Селчанице, те им је уједно била заједничка, додирна, тачка. Међна линија групе села Дежево, Сути и Бекова у Расу кретала се ,у Сађавач пут под Куријачу” и „, Куријачу по брегу како је од раније међа код брега у Бучије”, села Граничани „уз врх Копоритске планине” а Горажде у Будимљи „поврх Буковика” и ,и с ону страну Буковика иза Чемерне пољане”. ${ }^{14}$ Планине Јагодна, Чрни крш, Чемерно и Буковик помињу се у међама села Хмељнице и Рујишта у Зети. Њихова међна линија се кретала „у врх Јагодна” те „у Чрни крш” потом „поврх Чемерна” отуда „у врх Буковика” и затим „поврх Буковика у студенац". ${ }^{15}$ Бањском властелинству поклоњена је ,планина Јеребиње и окрајци јој” а њене међе су ишле „, Камичак” те „под Бериње” и ,уу врх Курила”. ${ }^{16}$ У међама планина Баба, Гозбаба, Витицрев, Јеленак, Чахор и Драгојло као погранични ентитет помиње се планина Шекулар а Чрним горама планина Липовица. ${ }^{17}$

Из Дечанских хрисовуља дознаје се да је међа села Коморане ишла „на планину” а села Велика „у планину Драгојла” и „планину Ржана”. ${ }^{18}$ Међа села Добра Река водила је „по гребену Требјачке планине” и „по гребену поред Досуђске

12 Српски митолочки речник, приредили Шпиро Кулишић, Петар Ж. Петровић и Никола Пантелић, Београд 1998, 116-117 (П. Ж. Петровић).

13 Љубомир Ковачевић, Светостефанска хрисовуља, Споменик IV (1890), 2; Ватрослав Јагић, Светостефански хрисовуљь краља Стефана Уроша II. Милутина, из Старога Сараја, изнесла на свијет Земаљска влада за БиХ са 4 снимка, Беч 1890, 7-8; Задужбине Косова. Споменици и знамења српског народа, Призрен - Београд 1987, 316; Према убикацији топонима на терену, међник Лисац је данашња планина Лисац, Брезова глава је планина Брезовица а Козице су данашње планине Кознице, Снежана Божанић, Реконструкиија међа ибарског језгра светостефанског властелинства, Манастир Бањска и доба краља Милутина: Зборник са научног скупа одржаног од 22. до 24. октобра 2005. године у Косовској Митровици, Ниш - Косовска Митровица - Бањска 2007, Филозофски факултет у Косовској Митровици Центар за црквене студије у Нишу, 55-72.

${ }^{14}$ љ. Ковачевић, Светостефанска хрисовуља, 2-4; В. Јагић, Светостефански хрисовуљ, 7, 12-14; 16-17; Задужбине Косова, 316, 318.

${ }^{15}$ љ. Ковачевић, Светостефанска хрисовуља, 5; В. Јагић, Светостефански хрисовуљ, 18-19; Задужбине Косова, 319. Јагодна је данашња планина Јагода, југоисточно од Хелмића, Чемерно је данашња планина Чемерно на албанској граници а Буковик је планина Буковић, на албанској граници. Погледати: Sekcija Titograd 2, (677-2) 1 : 50000, Izdanje Vojnogeografskog instituta, Beograd 1984.

16 љ. Ковачевић, Светостефанска хрисовуља, 5; В. Јагић, Светостефански хрисовуљ, 21; Задужбине Косова, 319. Камичак је планински врх Камлик, Бериње је планински врх Берим, а Курил је планински врх Курило, на Сувој планини.

17 Љ. Ковачевић, Светостефанска хрисовуља, 5-6; В. Јагић, Светостефански хрисовуљ, 21-23; Задужбине Косова, 319.

${ }^{18}$ Павле Ивић, Милица Грковић, Дечанске хрисовуље, Нови Сад 1976, ДХ I (207-213), ДХ ІІ (40), ДХ III (2002-2013); Исто, ДХ І (214-218), ДХ ІІ (40-41), ДХ ІІІ (2029-2037); Задужбине Косова, 337. 
планине” те „по гребену до планине грнчаревске у Липовицу и путем низ Липовицу”. ${ }^{19}$ При описивању међа села Сјерош бележи се да је међа ишла како река Лопачтица „извире из планине” и како Рибник ,„извире из планине”. ${ }^{20}$

У Светоарханђеловској хрисовуљи при опису међа засеока Љубижње Скробишта помиње се „пут који води од Љубижње више Скробишта у планину” а отуда је међа ишла „више пута што се налази до планине” док се у међама села Машутишта бележе планина Грмовата и Болован с Висетицама. ${ }^{21}$

Врхови брда и планина су јасни и прецизни природни међници. Та места представљају станишта вила загоркиња и божанстава, према српској митологији. На њима виле ноћу, по месечини, певају и играју у колу. Према неким веровањима на „врховима брда небо се ослања на земљу”.22 Одатле се види цео свет, па се с њих може отићи на небо.

Према Грачаничкој повељи међа села Грачаница, Сушица и Селце кретала се ,по брегу право на Оштри врх” а затим од Оштрог врха даље. ${ }^{23}$

Као погранични ентитети планине Јеребиње на властелинству Св. Стефана у Бағској јављају се планински врх Камлик, Берим и Курил. ${ }^{24}$ На истоименом властелинству, као међник прве групе прилога дарованих од стране краља Милутина који су били лоцирани на левој обали Ибра забележен је Црни врх. Међа Ибарског језгра Светостефанског властелинства ишла је, између осталог, „поврх Кашља по брегу у Златни камен”. ${ }^{25}$ Кашаљ је предео на Рогозни а Златни камен је истоимени врх који и данас фигурира на терену. Заједничка међа групе села у Расу, Беково, Полаз и Хропалица водила је од села Трнаве према планинском врху Близанац, који и данас постоји на терену под истим именом. ${ }^{26}$ Међа села Хмељница и Рујишта, у Зети, ишла је „од Цемве где се зове у Утрж на врх” и „отуд у врх Буковика”, те „поврх Буковика” и „отуда у врх Јагодна” затим „поврх Чемерна”,

\footnotetext{
${ }^{19}$ П. Ивић, М. Грковић, ДХ І (245-253), ДХ ІІ (45), ДХ ІІІ (2224-2240); Задужбине Косова, 338.

${ }^{20}$ П. Ивић, М. Грковић, ДХ І (-), ДХ ІІ (48), ДХ ІІІ (1404-1417); Задужбине Косова, 339.

${ }^{21}$ J. Шафарик, Хрисовуља иара Стефана Душана којом оснива манастир Св. Архангела Михаила и Гаврила у Призрену године 1348?, Гласник ДСС XV (1862), 273, 278; Задужбине Косова, 347-348.

${ }^{22}$ Српски митолошки речник, 116-117 (П. Ж. Петровић). Врхови многих брда и планина „у Србији називају се Вилинско коло или Виље коло, јер се веровало да су на њима виле играле”,; Словенска митологија, редактори Светлана М. Толстој и Љубинко Раденковић, Београд 2001.

${ }^{23}$ Миливој Павловић, Грачаничка повеља, Гласник СНД III (1928), 126; С. Новаковић, Законски спомениич српских држава средњег века, Београд 1912 (репринт 2005²), 633 (I) Задужбине Косова, 323.

24 Љ. Ковачевић, Светостефанска хрисовуља, 5; В. Јагић, Светостефански хрисовуљ, 21; Задужбине Косова, 319; За убикацију ових топонима погледати војногеографску карту: Sekcija Kosovska Mitrovica 2, (630-2) 1 : 50000, Izdanje Vojnogeografskog instituta, Beograd 1984

${ }^{25}$ љ. Ковачевић, Светостефанска хрисовуља, 2; В. Јагић, Светостефански хрисовуљ, 6-7; Задужбине Косова, 316; С. Божанић, Ибарско језгро Светостефанског властелинства, Нови Сад - Сремска Митровица 2006, 98-100.

${ }^{26}$ љ. Ковачевић, Светостефанска хрисовуља, 4; В. Јагић, Светостефански хрисовуљ, 14-15; Задужбине Косова, 318; Данас на терену постоји Горња и Доња Трнава, код Новог Пазара. За прецизну убикацију погледати: Sekcija Sjenica 4, (579-4) 1 : 50000, Izdanje Vojnogeografskog instituta, Beograd 1984.
} 
села Граничани уз „уз врх Копоритске планине, од врха планине падином до пута” а Горажде у Будимљи ,поврх Буковика”. ${ }^{27}$

У Дечанским хрисовуљама „Велики врх” се јавља као погранични ентитет села Коморане (Комарани) а „Планински врх” села Серош. ${ }^{28}$

У Светоарханђеловској повељи врх брда Цвилина, код Призрена, јавља се као погранични ентитет села Вишеград и Лесковац, док се „Пешчани врх” и „врх Ранетац” јављају као међаши манастирских планина. Гранична линија села Тмава кретала се „по венцу у Чрни врх” а Јеленца „по врху над Млаке”. ${ }^{29}$

Према Раваничкој повељи међа села Прилепница водила је на „врх брда Драганца” а села Будрези „на врх Височице”. ${ }^{30}$

У српским средњовековним повељама као међник села, групе села, забела и катуна јављају се главе планина и брда, тј. њихови врхови. ${ }^{31}$

Из Светостефанске повеље дознаје се да се међна линија села Селчанице кретала „уз брег у Чрноглављу главу” и „у Лисац, у Брезову главу”, села Граничана „у Обрамовску главу, где се улива Чрнинов поток у Добруницу” а села Дежево, Сути и Беково, у Расу, „од стене по коси у Велији главу, од Главе по коси ка Богдановцу” и „и поред потока у Медвеђу главу, од Главе низ поток”. ${ }^{32}$

Према Светоарханђеловској повељи међна линија забела Крушчица протезала се „од Градишта у Кобиљу главу”, те од „Кобиље главе у Милшина селишта” и „на Равну главу”, села Вранић „од Добрих водица у Букову главу”, села Тудорче на „Остру главу” и „у Кобиљу главу”, катуна Голубовци „у Пешчану главу”, а катуна Гунцати у „Облу главу”. ${ }^{33}$

Према Раваничкој повељи атар села Будрези био је стрмовит. Његови доминантни ороними су планина Височа и „Радивојева глава” као један од врхова од којег се међа даље креће „низ брдо”. Описивање међа села Чрниловац завршава се код „Мнинске главе”. Међа села Војинци ишла је на „Летничју главу”. ${ }^{34}$

Поводом спора око атара села Ливоче између хиландарског пирга Св. Василија и властелина Николе Гоисалића кнегиња Милица са синовима Стефаном и

\footnotetext{
${ }^{27}$ Ђ. Ковачевић, Светостефанска хрисовуља, 2, 4-5; В. Јагић, Светостефански хрисовуљ, 7, 16-19; Задужбине Косова, 316, 318.

${ }^{28}$ П. Ивић, М. Грковић, ДХ І (207-213), ДХ ІІ (40), ДХ ІІІ (2002-2013); Исто, ДХ І (-), ДХ ІІ (48), ДХ ІІІ (1404-1417); Задужбине Косова, 337-339; Р. Ивановић, Дечанско властелинство, историјско-географска обрада, 197-198.

${ }^{29}$ J. Шафарик, Хрисовуља ияара Стефана Душана, 283, 300-301; Задужбине Косова, 348-349, 352; Синиша Мишић, Татјана Суботин-Голубовић, Светоарханћеловска повеља, Беогрда 2003, 40-57.

${ }^{30}$ Врднички препис повеље, Александар Младеновић, Повеље кнеза Лазара, Београд 2003, 60; Раванички препис, Исто, 118. Брдо Драганац се налази северозападно од Прилепнице. Планина Височа се налази јужно од села Доња и Горња Будрига.

${ }^{31}$ Rječnik JAZU III, obrađuje P. Budmani, Zagreb 1887-1891, 164-173; Речник српскохрватског књижевног и народног језика САНУ III, Београд 1965, 272-275.

${ }^{32}$ Споменик IV, 2-4; В. Јагић, Светостефански хрисовуљ, 7-8, 12-14; Задужбине Косова, 316. Према убикацији топонима Брезова глава је планина Брезовица, Лисац планина Лисац а Галич брдо Галич.

${ }^{33}$ Ј. Шафарик, Хрисовуља ичара Стефана Душана, 276, 278, 292; Задужбине Косова, 347-348, 350-351.

${ }^{34}$ Врднички препис повеље, А. Младеновић, Повеље кнеза Лазара, 60-62; Раванички препис, Исто, 118120; Г. Шкриванић, Раваничко властелинство, Раваница 1381-1981, 91.
} 
Вуком издала је повељу којом се детаљно утврђују његове међе. Као његови међници спомињу се Попова глава и Илијина глава. ${ }^{35}$ На том простору и данас постоји истоимени врх. ${ }^{36}$

Гребен је горњи, окомити део издужене планине, односно планинског венца. ${ }^{37}$ Бележи се у функцији пограничног ентитета српских средњовековних села и планина. Међе су водиле „по гребену”, „право гребеном” а понекад се само бележи планински гребен као доминантан ороним.

Планински гребен Крст јавља се, у Светостефанској хрисовуљи, као међник села Крушева у Плаву. ${ }^{38}$ у међама Крушева се помињу и планине Визитор, Бор, Крст и Ржана, што сведочи о надморској висини и конфигурацији овог терена.

У међама дечанског села Добра Река као погранични ентитет бележи се гребен. Његова међа је ишла „по гребену поред Досуђске планине” и „по гребену до планине грнчаревске у Липовицу”. ${ }^{39}$

Међа села Радеча које је припадало властелинству Св. Арханђела у Призрену водила је „право гребеном како се камен ваља” а као његов погранични ентитет бележи се и ,оштро камење”, што је сведочанство о конфигурацији овог терена. $^{40}$

Присуство стене као међника је директно сведочанство о географским приликама на одређеном терену. ${ }^{41}$ Оне се најчешће бележе као међници села и забела. Када се јављају у функцији међаша, стене се најчешће пописују са именом: Пчелиња стена, Вранова стена, Велија стена, Крајња стена, Девичја стена. Називи неких стена упућују на њихову величину, положај или присуство неких животињских врста. Међа је обично водила „од стене” и „у стену”.

Према Светостефанској хрисовуљи као граничник села Павље, два пута, се бележи стена. Његова међа је водила у „стену” и „од стене по брегу”. ${ }^{2}$ Ово село, удаљено $14 \mathrm{~km}$ од Новог Пазара, налазило се у котлини. Окружено је венцем

\footnotetext{
${ }^{35}$ Franc Miklosich, Monumenta Serbica spectancia historiam Serbiae, Bosnae, Ragusii, Vienne 1858 (репринт 2006³), 262-264, № CCXLVII (дат. 1389-1405); С. Новаковић, Законски споменици, 489-490, № IX (дат. 1394-1402); Actes de l' Athos, Actes de Chilandar II (ed. L. Petit et B. Korablev), Петроградь 1915, 548-550, № 71 (дат. 1389-1405); Задужбине Косова, 358 (дат. 1394-1402); Душан Синдик, Српска средњовековна акта у манастиру Хиландару, Хиландарски зборник 10 (1998), 74-75 (дат. 1394-1402). Оригинал (?) се налази у АХС под бр. 74, топографска сигнатура А 9/2.

${ }^{36}$ Атанасије Урошевић, Топоними Косова, СЕ3 89 (1975), 55.

${ }^{37}$ Речник српскохрватског књижевног и народног језика САНУ III, 601-602.

38 љ. Ковачевић, Светостефанска хрисовуља, 5; В. Јагић, Светостефански хрисовуљ, 17; Задужбине Косова, 319; Д. Боричић, Плав и Гусиње, Београд 1926, 28.

${ }^{39}$ П. Ивић, М. Грковић, ДХ І (245-253), ДХ ІІ (45), ДХ ІІІ (2224-2240); Задужбине Косова, 338.

${ }^{40}$ J. Шафарик, Хрисовуља ичара Стефана Душана, 281; С. Новаковић, Законски споменици, 689 (LXIX); Задужбине Косова, 348.

${ }^{41}$ Вук Стефановић Караџић, Српски рјечник, Београд 1975, 715; Vladimir Mažuranić, Prinosi za hrvatsko pravno-povjestni rječnik II, Zagreb 1908-1922, 1371, за стену бележи да је то „,sахит, кри, камењак, хрид, хридина, хруст, клис, лит, литица. У неким случајевима означава и развалине, разбацано камење зидова". Именица saxum -i, n. - на латинском језику означава камен, малу стену, хрид; Rječnik hrvatskoga ili srpskoga jezika JAZU XVI, Zagreb 1956-1958, 526.

${ }^{42}$ љ. Ковачевић, Светостефанска хрисовуља, 4; В. Јагић, Светостефански хрисовуљ, 15; Задужбине Косова, 318; Г. Шкриванић, Властелинство св. Стефана у Бањској, ИЧ VI (1956), 187-188.
} 
сеоских брда: Рудине (1164), Дијелови, Окошанско брдо, Стране и Главица према Осаоници. Стена као погранични ентитет јавља се и у међама села Храстије. ${ }^{43}$ Као погранични ентитет села Гошево, под Јелечем, наводи се „Пчелиња стена” која се налазила у близини потока Драгочај. У међама овог села помиње се „пут стрменички”, што може да свеочи о стрмовитом терену у овом крају. ${ }^{44}$

Према Светоарханђеловској хрисовуљи међа села Кориша водила је „од реке у Велију стену” и „од стене у Дрвену цркву”. Граница забела Крушчица протезала се „од Сврчка у Врању стену, и од Врање стене у Градиште” те „у Пчелињу стену”, села Средска „у Пчелињу стену” а села на Средској по имену Село „по брегу у Крајњу стену” и „од стене у Лисине”. Описивање међа села Тмава почиње и завршава се код „Девичје стене”, као доминантног оронима овог прилога. $^{45}$

У Раваничкој повељи помињу се Пчелиња и Вранова стена као погранични ентитети села Прилепница. ${ }^{46}$

Као међник српских средњовековних села јављају се хриди. Још је В. С. Караџић забележио израз: „Тер се међе низ високе хриди”. ${ }^{4}$

У Плавско-Гусињској области Дечанском властелинству било је додељено село Коморане (Коморача) ${ }^{48}$ у чијим међама се као погранични ентитет бележи „хрид”, док се међа села Трепче са Досуђем завршавала код „хрида”, у близини пута. $^{49}$

„Хрид” се јавља као погранични ентитет светоарханђеловског села Бучије, које се простирало на надморској висини од $1000 \mathrm{~m} .{ }^{50}$

Стрмине представљају стране брда и планина, њихове обронке. Јављају се приликом описивања међа да би се што конкретније и сликовитије описао неки терен у средњем веку. Оне директно сведоче о географској ситуацији на неком терену. ${ }^{51}$

Приликом описивања међама бањског села Јелићи бележи се да међа иде „стрмо у реку”. ${ }^{52}$ Иако се у даљем опису међа овог села не помињу планине и брда,

\footnotetext{
43 љ. Ковачевић, Светостефанска хрисовуља, 5; В. Јагић, Светостефански хрисовуљ, 20-21; Задужбине Косова, 319.

44 љ. Ковачевић, Светостефанска хрисовуља, 4; В. Јагић, Светостефански хрисовуљ, 16; Задужбине Косова, 318. Гошево је данас удаљено 9 km од Новог Пазара и лежи на десној страни реке Јошанице. Дели се на засеоке: Горње и Доње Гошево и Пољане.

${ }^{45}$ J. Шафарик, Хрисовуља ияара Стефана Душана, 273, 276, 280, 283; Задужбине Косова, 347-348.

${ }^{46}$ Врднички препис повеље, А. Младеновић, Повеље кнеза Лазара, 60; Раванички препис, Исто, 118.

${ }^{47}$ В. С. Караџић, Српски рјечник, 806; Ј. Чолић, Речник латинско-српско-хрватски, Београд 1991, 448, именица rupes, -is, f. - стена, крш, гребен.

${ }^{48}$ П. Ивић, М. Грковић, ДХ І (207-213), ДХ ІІ (40), ДХ ІІІ (2002-2013); Задужбине Косова, 337.

${ }^{49}$ П. Ивић, М. Грковић, ДХ І (318-223), ДХ ІІ (41), ДХ ІІІ (2058-2068); Задужбине Косова, 337; Р. Ивановић, Дечанско властелинство, историјско-географска обрада, 198.

${ }^{50}$ J. Шафарик, Хрисовуља ияара Стефана Душана, 281; С. Новаковић, Законски споменици, 689 (LXVIII); Задужбине Косова, 348.

${ }^{51}$ В. С. Караџић, Српски рјечник, 719; Rječnik hrvatskoga ili srpskoga jezika JAZU XVI, 755.

52 љ. Ковачевић, Светостефанска хрисовуља, 4; В. Јагић, Светостефански хрисовуљ, 16; Задужбине Косова, 318.
} 
историјско-географска истраживања пружају подробније податке о овом терену. Село постоји и данас као Горње и Доње Јелиће. Географски, припада Ибарском Колашину, тј. подручју у долини горњег Ибра, између Рогозне, Мокре планине, Косова и Рибарићке клисуре, која га одваја од Штавице и рожајског краја. ${ }^{53}$

Приликом описивања међа у српским средњовековним повељама наилази се и на рт, део земљишта који се диже у висину или се усеца између падине. ${ }^{54}$ у међама села Окопац Горњи помиње се Церови рт ${ }^{55}$ а села Чрниловац Бретови рт, према Раваничкој повељи. ${ }^{56}$

Поред планина и гора у српском средњовековном дипломатичком материјалу често се спомињу и брда, као природни, јасно уочљиви, међници. ${ }^{57}$ То је узвишење које се по свом облику разликује у односу на суседно земљиште. Брда се заједно са селима бележе и као предмет даривања средњовековним властелинствима. ${ }^{58}$ У средњем веку се правила јасна разлика између брда и планине. Манастиру Св. Пантелејмона на Св. Гори била су поклоњена села: Мокрани, Макријево, Зубовце, Борисово и Габрово са ,планином и брдом”. 59

Брдо се у највећем броју случајева јавља као међник села, понекад засеока и далеко ређе катуна, зимовишта, селишта и планина. Међа неког прилога могла је ићи „уз брдо” и „низ брдо” при чему се истиче стрмина брда. Веома често, наилази се на податаке да међна линија иде „од брда”, „преко брда”, ,у брдо”, „под брдо” и „на брдо”.

Према Светостефанској хрисовуљи као погранични ентитет села Бањске и суседних му села, на левој обали Ибра, помињу се „Голо брдо” и „Добро брдо”. Међна линија села Дежево, Сути и Бекова у Расу протезала се „у Стефањо брдо” те „под Плано брдо”, потом „уз Грдијино брдо” и „од брда у Сађавач пут под Куријачу” а села Сочанице „у Суху” те „од Бориковца под планину уз брег, у Дабрхаву како Дабрхава упада у Ибар” и ,у Галич”. ${ }^{61}$ Гранична линија села

\footnotetext{
${ }^{53}$ М. Лутовац, Ибарски Колашин, антропогеографска испитивања, Српски Е3 LXVII, Београд 1952, 61; Гавро Шкриванић, Властелинство св. Стефана у Банској, ИЧ VI (1956), 188; Раде Михаљчић, Јелеч, Прошлост и народно сећање, Београд 1995, 205-207.

${ }^{54}$ Rječnik hrvatskoga ili srpskoga jezika JAZU XVI, 204.

${ }^{55}$ Врднички препис повеље, А. Младеновић, Повеље кнеза Лазара, 59; Раванички препис, Исто, 117; Г. Шкриванић, Раваничко властелинство, Раваница 1381-1981, Београд 1981, 83-99.

${ }^{56}$ Врднички препис повеље, А. Младеновић, Повеље кнеза Лазара, 62; Раванички препис, Исто, 120.

${ }^{57}$ В. С. Караџић, Српски рјечник, 41; V. Mažuranić, Prinosi za pravno-povijesni rječnik I, 97, „,brdo-mons”.

${ }^{58}$ Брда додељена са селима поседовали су, између осталих, следећи манастири: Хиландар, С. Новаковић, Законски споменици, 421 (13); 423 (13); Св. Пантелејмона на Светој Гори, Исто, 511 (II); 511 (III); 511 (IV); 511 (V); 511 (VI); Хтетовски манастир, Исто, 659 (XXIV); 659 (XXV); Трескавац, Исто, 667 (I); 670 (IV); те манастир Св. Богородице у Охриду, Исто, 673 (X).

${ }^{59}$ C. Новаковић, Законски споменици, 511 (II); 511 (III); 511 (IV); 511 (V); 511 (VI).

${ }^{60}$ Оба међника постоје до данашњих дана под истим именом, код Ибарског Колашина. љ. Ковачевић, Светостефанска хрисовуља, 2; В. Јагић, Светостефански хрисовуљ, 6-7; Задужбине Косова, 316.

61 љ. Ковачевић, Светостефанска хрисовуља, 2-4; В. Јагић, Светостефански хрисовуљ, 6-7, 12-14; Задужбине Косова, 316, 318. Сви наведени топоними могу се убиковати и данас на терену.
} 
Горажде у Будимљи кретала се „преко брда у зовину”, села Хмељница и Рујишта у Зети „поврх Великога брда на Облу главу”, а Чрним горама „право у брдо”. ${ }^{62}$

Према Дечанским хрисовуљама међа села Бабе и Добри Дол ишла је „преко брда до крстова”, села Велика „у брдо”, Љуболића „у брдо”, Чрним горама између Плава и Будимља „уз брдо” а Светог Николе у Ботуши „од брда”. ${ }^{63}$ Као погранични ентитет села Грмочел јавља се „Илијино брдо” а села Улоћани „Пешчано брдо”. ${ }^{64}$ Међа Алтину је ишла „према Тлстом брду” док се граница зимовишта Модра Слатина протезала на „Тлсто брдо”. ${ }^{65}$ Приликом описивања међа, израз „низ брдо” јавља се у функцији међника села Чабић, Куманова, Коморани те Штитарице с Ђурђевиком. ${ }^{66}$

Међа селишта Пустомулчу према Призренској повељи водила је „од локве низ брдо доле у Велику реку опољску” и ,преко потока зрзевског на брдо како се камен ваља у поток зрзевски". ${ }^{67}$

У Светоарханђеловској повељи, бележи се да међа села Пећани иде „низ брдо на реку”, Целина „од крста у Вражје брдо”, села Тудорче у Топлици „низ брдо” а села Селци „преко брда на Велики врх”. ${ }^{68}$ Међа села Радеча с засеоком Радешицом водила је „на брдо”, засеока Крсти „низ брдо на Равну пољану”, села Купелник „под Храстово брдо” а катуна Гунцати „у брдо”. 69

Из Раваничке повеље, кнеза Лазара, дознаје се да је међа села Ленитковци ишла „уз брдо”. ${ }^{70}$

Као погранични ентитет села, засеока, планина, катуна и забела у средњовековним повељама бележи се брег тј. мало брдо. ${ }^{71}$ Брег има благе падине и слабо изражено подножје.

Према Грачаничкој повељи међа села Грачаница, Сушица и Селце кретала се ,по брегу на орану пољану”. ${ }^{72}$

\footnotetext{
${ }^{62}$ Споменик IV, 4-6; В. Јагић, Светостефански хрисовуљ, 16-17, 18-19, 22-23; Задужбине Косова, 318, 319.

${ }^{63}$ П. Ивић, М. Грковић, ДХ І (156-159), ДХ ІІ (15), ДХ ІІІ (623-639); Исто, ДХ І (214-218), ДХ II (40-41), ДХ ІІІ (2029-2037); Исто, ДХ І (144-150), ДХ ІІ (11), ДХ ІІІ (399-411); Исто, ДХ І (231-238), Исто, ДХ ІІ (43), ДХ ІІІ (-); ДХ І (-), ДХ ІІ (59), ДХ ІІІ (2718-2726); Исто, Задужбине Косова, 330-331, 337-338, 341.

${ }^{64}$ П. Ивић, М. Грковић, ДХ І (159-164), ДХ ІІ (18), ДХ ІІІ (743-752); Исто, ДХ І (-), ДХ ІІ (19), ДХ ІІІ (827-830); Задужбине Косова, 331.

${ }^{65}$ П. Ивић, М. Грковић, ДХ І (192-200), ДХ ІІ (38-39), ДХ ІІІ (1932-1949); Исто, ДХ I (-), ДХ ІІ (56), ДХ III (2587-2593); Задужбине Косова, 337, 341.

${ }^{66}$ П. Ивић, М. Грковић, ДХ І (165-176), ДХ ІІ (24-25), ДХ ІІІ (1057-1082); Исто, ДХ І (-), ДХ ІІ (26-27), ДХ ІІІ (1164-1181); Исто, ДХ І (207-213), ДХ ІІ (40), ДХ ІІІ (2002-2013); Исто, ДХ І (176-184), ДХ ІІ (25), ДХ ІІІ (1082-1094); Задужбине Косова, 332-333, 337.

${ }^{67}$ С. Новаковић, Законски споменици, 641 (XXII); Задужбине Косова, 326

${ }^{68}$ Ј. Шафарик, Хрисовуља ичара Стефана Душана, 278, 302, 304; С. Новаковић, Законски споменици, 688 (XLVII); 694 (CXXX); 696 (CXLII); Задужбине Косова, 347-348, 352-353.

${ }^{69}$ Ј. Шафарик, Хрисовуља ичара Стефана Душана, 281, 286, 287, 290; Задужбине Косова, 348-350.

${ }^{70}$ F. Miklosich, Monumenta Serbica, 199.

${ }^{71}$ В. С. Караџић, Српски рјечник, 43, брег, collis; V. Mažuranić, Prinosi za hrvatsko pravno-povjestni rječnik I, Zagreb 1908, 100, breg, brig, m., collis, monticulus, ali i „ripa, litus, dakle hum, brdo, ali i obala uz more $i$ reku”.
} 
Према Светостефанској хрисовуљи међа села Стрелац ишла је „од градишта право по брегу чичавичком”, Тушимље „по брегу на Ровце” а села Беково, Полаз и Хропалица „с Куријаче низ Грдин брег”. ${ }^{73}$ Граница села Горажде у Будимљи водила је „по брегу покрај дола” и отуда „по брегу у крушку” те „по брегу у врбу, и у студенац” потом „у тиковски брег” и „уз брег у брезје” те „по брегу поврх Буковика” а Крушева у Плаву „по брегу над бор” и „,по брегу у Ражану”.74 Међа диношких планина је водила „од Скрботнице уз брег” а планина Баба, Гозбаба, Витицрев, Јеленак, Чахор и Драгојло „у обли брег”. ${ }^{75}$

Из Дечанских хрисовуља се види да је атар села Дечани са засеоцима ишао „од Чрвенога брега по могилу у реку”. ${ }^{76}$

Према Светоарханђеловској повељи у функцији међника забела Крушчица помиње се више брегова од којих се за један изричито бележи да је „први брег”. Међа забела у Слатини водила је једним делом „од луга уз брег истим оним брегом који води до патковског брега, и истим оним брегом идући како силази у Пантократорове међе”, засеока Љубижње Скробишта „низ брег” а засеока Крумада „на врело по брегу”. ${ }^{78}$ Граница катуна Добрушинаца Јанчишта протезала се ,уз брег у Дугу пољану” те ,уз брег у гомилу” а према Пагаруши „низ брег до Пантократорова хрисовуља”, катуна Голубовци „уз брег право код Будислављих кућишта, право уз брег, и преко брега у студенац” а катуна Гунцати „низ брег у горњи крај Милешеве баре". ${ }^{79}$

У Раваничкој повељи забележен је Црвени брег као међник села Поточац. ${ }^{80}$

До или дол, равно земљиште окружено брдима, често се бележи у функцији граничника дарованих прилога. ${ }^{81}$ Удолине се јављају у пограничном систему села, групе села, засеока, забела, зимовишта, катуна и планина. Међа је могла да иде „у дол”, „на дол”, „долом”, „из дола” и „код дола”. Долови су најчешће пописани са личним именом.

Из Светостефанске хрисовуље јасно се види да се долови често бележе у функцији граничника дарованих прилога. Најчешће су забележени са именом. Војков дол се јавља у међама прве групе дарованих прилога на левој обали Ибра,

\footnotetext{
${ }^{72}$ М. Павловић, Грачаничка повеља, 126; С. Новаковић, Законски споменици, 633 (I) Задужбине Косова, 323.

73 љ. Ковачевић, Светостефанска хрисовуља, 3-4; В. Јагић, Светостефански хрисовуљ, 9-10, 14-15; Задужбине Косова, 316-318.

74 Љ. Ковачевић, Светостефанска хрисовуља, 4-5; В. Јагић, Светостефански хрисовуљ, 16-17; Задужбине Косова, 318-319.

75 Љ. Ковачевић, Светостефанска хрисовуља, 5-6; В. Јагић, Светостефански хрисовуљ, 21-22; Задужбине Косова, 319.

${ }^{76}$ П. Ивић, М. Грковић, ДХ І (132-133), ДХ ІІ (4), ДХ ІІІ (14), (39), (51); Задужбине Косова, 328.

${ }^{77}$ J. Шафарик, Хрисовуља ичара Стефана Душана, 277; С. Новаковић, Законски споменици, 687 (XLI); Задужбине Косова, 347.

${ }^{78}$ Ј. Шафарик, Хрисовуља ичара Стефана Душана, 273, 283, 287; Задужбине Косова, 347, 349.

${ }^{79}$ Ј. Шафарик, Хрисовуља цуара Стефана Душана, 292; С. Задужбине Косова, 350-351.

${ }^{80}$ Врднички препис повеље, А. Младеновић, Повеље кнеза Лазара, 61; Раванички препис, Исто, 119.

${ }^{81}$ Rječnik JAZU II, obradili Đ. Daničić, M. Valavac, P. Budmani, Zagreb 1884-1886, 602-603; Речник српскохрватског књижевног и народног језика САНУ IV, Београд 1966, 369-370.
} 
Прапратни дол села Бање, Волуји дол и Трнов дол села Беково, Полаз и Хропалица, Милетин и Купусов дол села Дежево, Сути и Беково а Лесков долац у међама Храстију. ${ }^{82}$ Безимени дол се јавља као међник села Осојани и Горажде. ${ }^{83}$

Према Дечанским хрисовуљама међник села Љуболићи је „Средњи дол”, села Чабић „Сухи дол”, Штитарице с Ђурђевиком „Дубоки дол” и „други дол”, села Грнчарева „Јаворови дол” а села Зерзево „Медвеђи дол”. ${ }^{84}$ Међа села Стрелац ишла је ,у врело уз Кобиљи дол”, села Бабе „на Братотинов дол”, Куманова и Радојева „у дол” и „уз дол”, Сушице „у Пасји дол” а зимовишта Модра Слатина „код Клобучарева дола". 85

У Светоарханђеловској повељи долови се бележе у међама села, засеока, катуна, планина, забела и зимовишта. Међа засеока Љубижиње Скоробишта према Кориши ишла је „на Драгшањ дол”, села Србице од Немишља „падином у Лисичији дол”, села Ошвања с Роговом „како упада Дубоки дол у Дрим”, села Сењани према Дубљанима „од потока уз дол на брег” а између села Пирани и Крушија „на Сињи камен над путем на долу”. Заједнички међаш села Речани и Исаврово према Сопину био је Чрни дол. Граница села Пећани протезала се „на Обрадов дол”, села Пакиша с Кошариштем „на Стипан дол”, села Лесковац „на Симен дол”, села Клчевиште „на Пасији дол”, села Селце „на Чрни дол”, села Целине „у Сухи дол”, а забела у Слатини „у Љешев дол”. Између осталог, међна линија села Средска с планином водила је „од цркве Света Петка право у дол”, села Радеча са засеоком Радешицом „из дола”, села Шикље у Горњем Пилоту „више забела у дол”, засеока Круимда „путем низ дол”, засеока Крсти „на Мокри дол” а забела Гнојна на Овчем пољу „како се камен ваља у Тудорчин дол”. Међа катуна Гунцати ишла је „Дубоким долом у брдо”, катуна Добрушинаца Јанчишта „у Велики дол на брег” а катуна Кострчани „на Лолајин дол”. Међа планине Синаинаца Хоругвица кретала се „на Војихнин дол” а планине Ограђеник „на Обрадач дол".

У Раваничкој повељи међа села Љубиње ишла је „низ дол”, села Српци „на дол” а села Камијево „на Дрењанску долину”. ${ }^{87}$

Пољане се у дипломатичком материјалу бележе у међама села, забела и катуна. Гранична линија могла да води ,у пољану”, „на пољану”, „над пољану” и ,ка пољанама”.

\footnotetext{
82 љ. Ковачевић, Светостефанска хрисовуља, 2-5; В. Јагић, Светостефански хрисовуљ, 6-7, 12-15, 2021; Задужбине Косова, 316, 318-319.

${ }^{83}$ љ. Ковачевић, Светостефанска хрисовуља, 4; В. Јагић, Светостефански хрисовуљ, 11-12, 16-17; Задужбине Косова, 318.

${ }^{84}$ П. Ивић, М. Грковић, ДХ I (144-150), ДХ ІІ (11), ДХ ІІІ (399-411); Исто, ДХ I (165-176), ДХ ІІ (24-25), ДХ ІІІ (1057-1082); Исто, ДХ І (176-184), ДХ ІІ (25), ДХ ІІІ (1082-1094); Исто, ДХ І (223-231), ДХ ІІ (42), ДХ ІІІ (2095-2109); Исто, ДХ I (255-260), ДХ ІІ (58), ДХ ІІІ (2661-2671).

${ }^{85}$ П. Ивић, М. Грковић, ДХ ІІ (9); Исто, ДХ ІІ (15), ДХ ІІІ (623-639); Исто, ДХ ІІ (26-27), ДX III (11641181); Исто, ДХ ІІ (50); Исто, ДХ ІІ (56), ДХ ІІІ (2587-2593).

${ }^{86}$ J. Шафарик, Хрисовуља иара Стефана Душана којом оснива манастир Св. Архангела Михаила и Гаврила у Призрену године 1348?, Гласник ДСС XV (1862), 273-274, 276, 277-278, 280- 283, 285-286, 290, 292, 300-302.

${ }^{87}$ Врднички препис повеље, А. Младеновић, Повеље кнеза Лазара, 61; Раванички препис, Исто, 119.
} 
Према Светостефанској хрисовуљи, међа села Осојани, у Кујавчи, ишла је „уз брег ка Војводиним кућама, ка пољанама” и „како спада брег у дуб над пољану к Лесковцу” а села Крушево „у Умоврен поток, посред пољца, иза стога у пољану". 88 Вучија пољана се бележи као међник села Стрелац а Хрељина пољана села Горажде, у Будимљи. ${ }^{89}$

У Светоарханђеловској повељи пољане се бележе као међници села, забела и катуна. Међна линија села Ошвања кретала се „од крста по брегу у Рујеву пољану”, забела Крушчица „по брегу у Мишју пољану”, катуна Гунцати „над Вучију пољану”, потом „из дола на Медвеђу пољану” и „преко брда на Татенове пољане” а катуна Јанчишта „уз брег у Дугу пољану”. Међаш села Кориша била је „Јаворова пољана". 90

Из Раваничке повеље се види да се гранична линија села Поточац протезала на „Велику пољану”. 91

\section{Извори и литература:}

Actes de l' Athos, Actes de Chilandar II (ed. L. Petit et B. Korablev), Петроградь 1915.

Барјактаревић, Мирко, О земљишним међама у Срба, Београд 1952.

Благојевић, Милош, Планине и пащъации у средњовековној Србији (XIII-XIV век), ИГ 2-3 (1966), 3-95.

Божанић, Снежана, Ибарско језгро Светостефанског властелинства, Нови Сад - Сремска Митровица 2006.

Божанић, Снежана, Реконструкиија међа ибарског језгра светостефанског властелинства, Манастир Бањска и доба краља Милутина: Зборник са научног скупа одржаног од 22. до 24. октобра 2005. године у Косовској Митровици, Ниш - Косовска Митровица - Бањска 2007, Филозофски факултет у Косовској Митровици - Центар за црквене студије у Нишу, 55-72.

Божанић, Снежана, Хидрографски међници у српским средњовековним повељама: друштвена, религијска и митолошка функиија, Зборник радова Извори о историји и култури Војводине, Нови Сад 2009, 43-64.

Задужбине Косова. Споменици и знамења српског народа, Призрен - Београд 1987.

Ивановић, Радомир, Властелинство манастира св. Арханђела код Призрена, историјскогеографска истражсивања, ИЧ VII (1957), 345-359.

Ивановић, Радомир, Властелинство манастира св. Арханђела код Призрена II, историјскогеографска истраживања, ИЧ VIII 1958 (1959), 209-253.

Ивановић, Радомир, Дечанско властелинство, историјско-географска обрада, ИЧ IV 19521953 (1954), 173-226.

Ивановић, Радомир, Земљьшни поседи Грачаничког властелинства, ИЧ ХІ (1961), 253-264.

\footnotetext{
88 љ. Ковачевић, Светостефанска хрисовуља, 3, 5; В. Јагић, Светостефански хрисовуљ, 11-12, 17; Задужбине Косова, 318-319.

${ }^{89}$ Љ. Ковачевић, Светостефанска хрисовуља, 3-4; В. Јагић, Светостефански хрисовуљ, 9-10, 16-17; Задужбине Косова, 316-318; Г. Шкриванић, Властелинство св. Стефана у Бањској, 189-190. Хрељина пољана се налази на северној падини планине Кацибер, код коте 1570.

${ }^{90}$ Ј. Шафарик, Хрисовуља изара Стефана Душана, 221, 273-274; Задужбине Косова, 347, 350.

${ }^{91}$ Врднички препис повеље, А. Младеновић, Повеље кнеза Лазара, 61; Раванички препис, Исто, 119.
} 
Ивић, Павле, Грковић, Милица, Дечанске хрисовуље, Нови Сад 1976.

Јагић, Ватрослав, Светостефански хрисовуљь краља Стефана Уроша II. Милутина, из Старога Сараја, изнесла на свијет Земаљска влада за БиХ са 4 снимка, Беч 1890.

Јиречек, Константин, Историја Срба II, Београд 1981.

Стефановић Караџић, Вук, Српски рјечник, Београд 1975.

Ковачевић, Љубомир, Светостефанска хрисовуља, Споменик IV (1890), 1-11.

Лексикон српског средњег века, приредили Сима Ћирковић и Раде Михаљчић, Београд 1999.

Mažuranić, Vladimir, Prinosi za hrvatsko pravno-povjestni rječnik I-II, Zagreb 1908-1922.

Miklosich, Franc, Monumenta Serbica spectancia historiam Serbiae, Bosnae, Ragusii, Vienne 1858 (репринт 20063).

Михаљчић, Раде, Јелеч, Прошлост и народно сећање, Београд 1995.

Мишић, Синиша, Међе у Светостефанској хрисовуљи, Манастир Бањска и доба краља Милутина: Зборник са научног скупа одржаног од 22. до 24. октобра 2005. године у Косовској Митровици, Ниш - Косовска Митровица - Манастир Бањска 2007, 43-53.

Мишић, Синиша, Унутрашње воде и њихово коришћење у средњовековној Србији, додатак ИГ 1-2/ 1990-1992, (1992), 1-79.

Мишић, Синиша, Суботин-Голубовић Татјана, Светоарханђеловска повеља, Београд 2003.

Младеновић, Александар, Повеље кнеза Лазара, Београд 2003.

Новаковић, Стојан, Законски спомениии српских држава средњег века, Београд 1912 (репринт $\left.2005^{2}\right)$.

Павловић, Миливој, Грачаничка повеља, Гласник СНД ІІІ (1928), 105-140.

Пурковић, Миодраг, Одређивање међа, Етнологија 1-2 (1940), 65-84.

Речник српскохрватског књижевног и народног језика САНУ III, Београд 1965.

Речник српскохрватског къижевног и народног језика СAHУ IV, Београд 1966.

Rječnik JAZU II, obradili Đ. Daničić, M. Valavac, P. Budmani, Zagreb 1884-1886.

Rječnik JAZU III, obrađuje P. Budmani, Zagreb 1887-1891.

Rječnik hrvatskoga ili srpskoga jezika JAZU XVI, Zagreb 1956-1958.

Синдик, Душан, Српска средњовековна акта у манастиру Хиландару, Хиландарски зборник 10 (1998), 9-151.

Соловјев, Александар, Одабрани споменици српског права (од XII до краја XV века), Београд 1926.

Српски митолошки речник, приредили Шпиро Кулишић, Петар Ж. Петровић и Никола Пантелић, Београд 1998.

Стојановић, Љубомир, Старе српске повеље и писма I-2, Београд - Ср. Карловци 1934 (репринт 2006²).

Чолић, Јован Д., Речник латинско-српско-хрватски, Београд 1991.

Урошевић, Атанасије, Топоними Косова, СЕЗ 89 (1975).

Шафарик, Ј., Хрисовуља ияара Стефана Душана којом оснива манастир Св. Архангела Михаила и Гаврила у Призрену године 1348?, Гласник ДСС XV (1862), 264-283.

Шкриванић, Гавро, Властелинство св. Стефана у Бањској, ИЧ VI (1956), 177-199.

Шкриванић, Гавро, Раваничко властелинство, историјско-географска истраживања, ИЧ XVIXVII 1966-1967 (1970), 235-253.

Шкриванић, Гавро, Раваничко властелинство, Раваница 1381-1981, Београд 1981, 83-99.

Топографске карте:

Sekcija Kosovska Mitrovica 2, (630-2) 1 : 50000, Izdanje Vojnogeografskog instituta, Beograd 1984

Sekcija Sjenica 4, (579-4) 1 : 50000, Izdanje Vojnogeografskog instituta, Beograd 1984.

Sekcija Titograd 2, (677-2) 1 : 50000, Izdanje Vojnogeografskog instituta, Beograd 1984. 
SNEŽANA BOŽANIĆ

\section{ORONYMS IN SERBIAN MEDIEVAL CHARTERS: THEIR MEMORIAL IN FUNCTION OF THE BORDER AREA ENTITY}

Relief is one of the most important and influential elements of the environment. All forms of the Earth's surface, i.e. its roughness and plane surfaces predetermine the type and forms of borders in a space. Mountains, hills, and mountain peaks, head, ridges, cliffs, rocks, steep slopes, headlands, valleys and pastures have a border role. Oronyms are clear, precise, easily visible, immobile, permanent borders, which exist under the same or similar name since the Middle Ages to the present day.

Keywords: Middle Ages, Serbia, border, Oronym, relief, mountain, hill, peak, ridge, rock, cape, slope, head, section, shall, field 